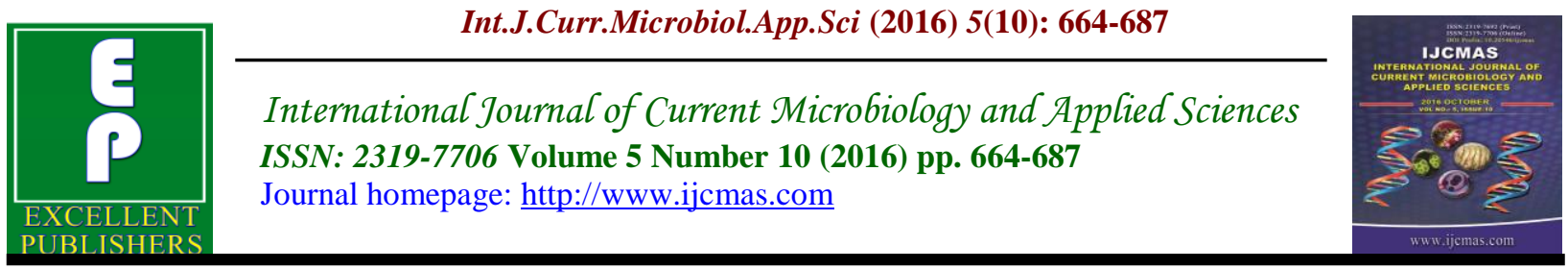

Review Article

http://dx.doi.org/10.20546/ijcmas.2016.510.074

\title{
African cassava Traditional Fermented Food: The Microorganism's Contribution to their Nutritional and Safety Values-A Review
}

\author{
Guira Flibert*, Tankoano Abel and Savadogo Aly \\ Laboratoire de Biochimie et d'Immunologie Appliquée (LaBIA) ; UFR-SVT, Université Ouaga \\ I Professeur Joseph KI-ZERBO, Ouagadougou, Burkina Faso. 03 BP 7021 Ouaga 03 \\ *Corresponding author
}

Keywords

Cassava;

Fermentation; traditional

Food;

Folates,

Africa.

\section{Article Info}

Accepted:

20 September 2016

Available Online:

10 October 2016

\section{A B S T R A C T}

Cassava fermented food have a long story in Africa. There are consumed decades ago. Some cassava fermented food as gari are largely spread in the continent. Every part of the African communities has developed their own process to ferment and use cassava. Ubuswage, Imikembe, Ikivunde, Inyange, ivunde, Mokopa are known as East African cassava fermented food when Chikwangue, Meduame-Mbong, cossette are known as Central Africa speciality. In west Africa, cassava fermented food found are Gari, Attiéké, Placali, Lafun and efubo, Kokondé, Agbelima, Loi-loi, Attoupkou, Dumby, Abacha, Kapok pogari, Bêdêkouma. The associate or involved microorganisms include, Lactobacillus, Leuconostoc, Lactococcus, Enterococcus as lactic acid bacteria and Bacillus. Yeast and moulds found are mainly Candida, Pichia, Hanseniaspora, Trichosporon, Geotrichum, Zygosaccharomyces, Saccharomyces, Kluyveromyces, as yeasts, Aspergillus, Penicillium, Mucor, Rhizopus as moulds. The biochemical compounds produce during fermentation include folates, several organic acids volatiles organics compound and others compounds. Cassava fermented food preservation, the starch functional increase, aroma and flavour enhancement, anti-nutrients reduction as well as cyanogen reduction as known as the impact of the fermentation process. The health benefit of cassava fermented foods concern their nutritional value, probiotics properties and their contribution to human immune system increase. Cassava fermented food are still produce in artisanal way and don't allow their nutritional values standardisation.

\section{Introduction}

Cassava is a food plants brought from the New World to the Tropical Africa where it does now establish (Blench, 2014). The utilization of cassava as food for America's societies began around the $18^{\text {th }}$ century before Christ (Blench, 2014). Cassava is grown widely in several parts of the world especially in the tropical regions and constitutes a significant proportion of the diet of the population. In Africa, it provides over $50 \%$ of the average daily caloric intake in some countries (Oyewole and Odunfa, 1992).In recent times, a number of regional programs have been initiated to breed 
improved varieties of cassava (Guira et al., 2016) to increase yield and resistance to diseases which are sometimes associated with the indigenous cassava varieties (Silvestre, 1989). Several processes including fermentation are applied for cassava postharvest preservation. To date fermentation remains the most popular process of cassava by-products valuation. It improves food preservation, nutritional value, hygiene and sanitary qualities, the energy density and organoleptic characteristics of foods (Flibert et al., 2016).Fermented foods have a long history in Africa. However the absence of writing culture in most of Africa makes their origin difficult to trace(Odunfa (1988)).Some reviews have been written on cassava fermented food in Africa, showing some aspects of these foods. This review aim then to establish relationship between cassava main fermented food in Africa and their associate microorganisms properties, the nutritional function, safety values and health benefits for human nutrition.

\section{Main cassava fermented food technology in Africa}

\section{Cassava fermented food in East Africa}

\section{Ubuswage}

Ubuswage is one of the main cassava fermented food in Burundi. It probably originated in the Southern part of the country, where the production had been located. Ubuswage is now produces in other parts of the country (Aloys and Zhou, 2006b).The equivalents of ubuswage in other countries are the Chikwange of Congolese, Myondo and Bobolo in Cameroon, Mboung in Gabon and Mangbele in Central Africa Republic. Other similar foods are also found in Congo Brazaville, Soudan and Angola(Aloys and Zhou, 2006b). For Ubuswage preparation, fibers are removed from roots and cassava roots are then peeled, washed. After boiling, cooking water is discharged and cassava roots are disintegrated for fiber removal. Cooked cassava is soaked in water after defibrering it for three days up to two weeks. The soaking water is change every two days. After this fermentation period, the water is discharged and fresh water is added. The cassava roots are underwent a second cooking. Cassava are then poured in a trough and pounded while hot until a thick smooth paste is obtained. The gelatinized cassava mass is rounded, shaped and wrapped in plantain leaves previously flamed(Aloys and Zhou, 2006b). Ubuswage shelf life is ranged between seven to eight days. It depends on seasons. Ubuswage have a low content of cyanide but require more labor for processing and preparation than do other cassava fermented from cassava(Aloys and Zhou, 2006b; Aloys and Angeline, 2009).

\section{Imikembe}

Imikembe is a Burundi's cassava fermented food.Cassava roots used for Imikembe preparation are first peeled, washed and boiled in a pot. Fibers are then removed by disintegrating cassava boiled root. After fibers removal, cassava roots are peel, wash and cut into pieces.

These pieces are sun dried for a day and soaking for four days up to a week in covered batch for fermentation(Aloys and Zhou, 2006b; Aloys and Zhou, 2006a). During soaking process, fermenting water is change every two days (Aloys and Zhou, 2006b). The obtained product is dried for five days to a week. The final product called Imikembe is eaten with beans and some legumes(Aloys and Angeline, 2009). 


\section{Ikivunde}

Ikivunde is a similar cassava fermented food like the Democratic Republic Congolese cossette.Ikivunde is found in Burundi and Rwanda(Aloys and Zhou; Aloys and Angeline, 2009). It is a fermented flour with the main processes ofInyange, another Burundi's cassava fermented food. The cassava better varieties are usually used for ikivunde production. Cassava roots used for ikivunde preparation are peeled, washed and cut into pieces. But some other producers don't peel it. The obtained cassava roots are soaked in a stream or stationary water for at least three days up to a week to allow them ferment until they become soft. The fermented roots are taken out and then sun dried on mats, racks, or roof houses. The drying process may take three days to one week. The cassava fermented root, cossette are pounded and sieved to yield fermented withte flour called ikivunde (Aloys and Zhou, 2006b; Aloys and Zhou, 2006a; Aloys and Angeline, 2009; Uyoh et al., 2009; Muoki and Maziya-Dixon, 2010; Lambri et al., 2013)

\section{Inyange}

Inyange is a cassava fermented food mainly found in Burundi (Nzigamasabo, 2012). It is essentially due to moulds fermentation. Inyange is similar to "mokopa", an Ougandan cassava fermented food. Cassava roots are peeled washed and cut into pieces. The pieces are sun-dried for a day. They are then heaped together and covered by plantain leaves or straw and left to ferment for five days. At the end of the fermentation, the pieces become soft and covered with moulds. The pieces are then scrapped, dried and pounded in a wooden mortar with a pestle and then sieved to get slightly dark colored flour: it is inyange. Inyange is made into a paste called "ubugali" by stirring it with boiling water over a low heat. It is usually eat with cassava leaves sauce, "isombe" and meats. Inyange had been found to be nutritionally higher than ikivunde but it retains higher antinutrients(Aloys and Hui Ming, 2006; Aloys and Zhou, 2006b; Aloys and Zhou, 2006a; Nzigamasabo, 2012).

\section{Kivunde}

Kivunde is a traditional cassava fermented food which is produced and consumed as popular in Tanzania. Kimaryo et al., (2000) have described spontaneous and controlled process for kivunde production. Cassava roots are washed with water to remove all dirt and peeled, diced into cubes of roughly $1-3 \mathrm{~cm}$ which were mixed. The cassava roots are again washed with boiled water. The roots are then submitted to the fermentation process for different time, from day up to a week according to the process (Lorri and Svanberg, 1995; Kimaryo et al., 2000; Mugula et al., 2003; Aloys and Hui Ming, 2006; Ray and Sivakumar, 2009; Anukam and Reid, 2009). By the end of the process, fermented roots obtained had a smooth texture and a pleasant fruity aroma.

\section{Mokopa}

Mokopa is a cassava fermented food from Ugandan, with mainly process like inyange(Ray and Sivakumar, 2009). Cassava roots used for mokopa production are first peeled and sliced. They are then surface dried for one to two hours before heaped together and covered with straw or leaves. The roots are submitted to three up to four days fermentation until the pieces become mouldy. The fermented and mouldy roots are again sun dried until the moulds have been scraped off. The processed and dried pieces are then milled into flour, mokopa which is prepared into a " $f u f u$ " called 
"kowan" in Uganda (Hahn, 1992; Aloys and Angeline, 2009). The growth of moulds on the root pieces increase the protein content of the final products three to eight times (Amey, 1987). This fermentation process is also very popular in other parts of East Africa as Tanzania, Rwanda, and Democratic republic of Congo (Hahn, 1989).

\section{Cassava fermented food in Central Africa}

\section{Chikwangue or cassava bread}

Chickwangue or cassava bread "bâton de manioc" is the most popular cassava processed food in Democratic Republic of Congo. It is also prepare and appreciate in many central African countries such as Cameroon, Gabon, Congo Brazaville, Central African Republic...The alternative names of chikwangue in the others communities are Ntuka, bugali, kmonmogo, chawada, bobolo, myondo, mboung, mangbele (Oyewole and Yemisi, 2003). The cassava roots are peeled and the rind is removed. Cassava roots are then soaking in water and left for three days up to two weeks to ferment until they become ssoft (Balagopalan, 2002b)to ferment until they become soft. The fibers are removed from the pulp, which are heaped on a rack for further fermentation or covered with leaves and pressed using heavy objects to drain off excess liquid. The pulp is then ground and sieved to produce flavor and pounded in a mortar. The fine pulp is steamed in pots. Chickwanghe is a very viscous paste, much thicker than fufu and appreciate in several countries(Nwankwo et al., 1989; Oyewole Olusola and Yemisi, 2003)

\section{Fermented boiled roots or Meduame-M- bong}

Meduame-m-bong or fermented boiled cassava roots is a cassava fermented based food originate from Cameroon. Meduame-
M-bong is eating with meats, fish, groundnuts, green leaves(Balagopalan, 2002b). Cassava roots used for meduame-mbong preparation are, washed and cut into large pieces. The cutted roots are then boiled for $30 \mathrm{~min}$ to a $1 \mathrm{~h}$. After discarding the water, cassava roots are again cut into small pieces and soaked in running water for 12 hours up to 36 hours(Oyewole, 1997; Raheem and Chukwuma, 2001; Balagopalan, 2002b; Oyewole and Asagbra, 2003; Enitan, 2010; Bull, 2011).

\section{Fufu}

Fufuis a food made from soaked fermented cassava. Fufu is a popular cassava food found in several African countries. The alternative names of fufu are foufou, foofoo, fulful, foutou, akpu, udep utim, farine, yakayeke, agbalima, water-fufu, according to Oyewole and Yemis, 2003. Fufu is traditionally produced and marketed as a wet, pasty food product. For the production of $f u f u$, the preliminary operations units are similar to the gari one Cassava roots are then peeled, washed, cut into thick chunks of $20 \mathrm{~cm}$ long, and soaked in water contained in earthen ware pots or in a slow flowing stream. The fermentation takes about four to five days. During this period, the cassava roots ferment and soften, releasing $\mathrm{HCN}$ into the soak water. A characteristic flavor of retted cassava meal also is produced. The retted roots are disintegrated in clean water, sieved, and the starchy particles that go through the sieve are allowed to settle for about 3 to 4 hours. The water is decanted while the sediment is packed into a cloth bag, tied, squeezed, and subjected to heavy pressure to expel excess water. The resulting meal is rolled into balls and cooked in boiling water for about 30 to 40 minutes. The cooked mass is pounded in a mortar with a pestle to produce a paste, fufu that can be eaten with sauce, soups, or 
stew. Fufu is also sold to consumers in wet form in small units packaged in plastic or polypropylene bags or in ready to eat cooked form. The balls are boiled in water and the soft dough is produced (Lancaster et al., 1982; Odunfa and Oyewole, 1998; Hahn, 1992; Bamidele et al., 2015).

\section{Cassava fermented roots or cossette}

Cossette are dried cassava fermented roots. It increases cassava post-harvest conservation. Cossette are one of the most popular cassava by products in Democratic Republic of Congo. Cossette are prepare by soaking or immersing wole or peeled fresh cassava (mainly the bitter one) in a stream or stationary water. The cassava roots are soaked for three up to six days. This operation unit also help to eliminate the toxic glycoside in bitter varieties. The fermented roots are then taken out, peeled and sundried. Depending on the weather, sun-drying takes two to five days. The dried cassava roots are called cossette, which are pounded and milled to yield fermented cassava flour (Lancaster et al., 1982; Hahn, 1989; Bamidele et al., 2015). This cossette also ground into flour to be used for the manufacture of secondary products, such as donuts and cake, obtained by frying a dough made with flour mixed with wheat flour.

\section{Cassava fermented food in West Africa}

\section{Gari}

Gariis a partially gelatinized (by toasting), free-flowing granular flour with a slightly fermented flavor and sour taste. Gari is now produces and consumes in West Africa, central Africa and east Africa. In West Africa, it is the most consumed and traded of all food products made from cassava roots. It is consumed either soaked in cold water or stirred in boiling water to make a stiff paste and consumed with choice soup. Garican be yellow (if fortified with red palm oil) or white, although gari from biofortified cassava is gaining popularity now. Seventy percent of cassava processed as human food is gari (Oduro et al., 2000; Moslehi-Jenabian et al., 2010). Its wide consumption is attributed to its relatively long shelf life and its easy preparation as a meal. There are variations in the gari produced within the sub-region in terms of physical, chemical and sensory qualities. However, the processing method used in this manual captures all variations as much as possible. It also emphasizes precautions on unit operations that have implications on finished product quality and safety (Olaoye et al., 2015; Adeniran and Ajifolokun, 2015; Zhu et al., 2015).

\section{Attiéké}

Attiéké is an essentially flavour starchy food, produced from fermented cassava root, originally prepared and consumed exclusively by some ethnic groups from Côte d'Ivoire. Nowadays attiéké is consumed in many neighboring countries such as Burkina Faso, Béni, Togo, Mali, Senegal(Assanvo et al., 2006; Djeni et al., 2011; Djéni et al., 2014; Flibert et al., 2016; Coulin et al., 2006). It is a steamed granular cassava (Oluwole et al.; Oyewole and Asagbra, 2003) meal ready-to-eat, couscouslike product, with slightly sour taste and whitish colour (Coulin et al., 2006; ZannouTchoko et al., 2011). Attiéké is similar to akeyke, a Ghaneen cassava fermented food but has a slightly sour taste and is eaten with milk or meat or vegetables. To produce attiéké, cassava roots are peeled, cut in pieces, washed and grated. During grating the cassava mass is mixed with about $10 \%$ of a traditionally prepared inoculum and about $0.1 \%$ palm oil. The inoculum is prepared by storing boiled cassava roots for 
three days in an unwashed jute bag previously used for inoculums preparation. The inoculated pulp is fermented overnight in covered bins. The fermentation softens the cassava mash and gives to this meals it characteristic flavour and texture (Firmin, 1995). After fermentation, the pulp is filled into bags and pressed for several hours. The pressed pulp is taken from the bags and squeezed through a sieve to obtain granules that are sundried and then cleaned to remove fibers and waste. The dried granules are steamed to produce attiéké, which is sold in small plastic bags as a ready-to-eat food. There is a difference in process then in the final product characteristic according to communities who produce it.

Placali is a cassava fermented food typically originates from Côte d'Ivoire. Placali is always consumed with sauc included generally both sources of protein ( animal and vegetable). Fermented cassava flour are energizing food due certainly to its high carbohydrate content. Placaliis prepared from fermented cassava dough. Cassava roots are first peeled and washed. And, the pulp is shredded and fermented. The obtained cassava dough is crushed, diluted, screened and poured gradually into a pot containing hot water. Under the effect of the heat produced by the fire, starch gelatinizes. It becomes sticky and then solidifies. A spatula is usually used to knead the cassava paste to get placali, a brittle cassava paste(Yao et al., 2015; Onzo et al., 2015; Kouamé et al., 2015).

\section{Lafun and efubo}

Lafun is another cassava popular fermented food in West Africa (Nigeria, Benin, Togo, Côte d'Ivoire). The alternative names of lafun are bombo, makessa, luku, nshima, exidzi, kanyanga, mapanga and maphumu, according to (Oyewole Olusola and Yemisi, 2003). Lafun is prepared by soaking cassava roots for three days. The roots are grated and allowed to sun dry. The product is then grounded into a very fine powder form. An estimated amount of boiling water is mixed into an estimated amount of lafun flour. It is allowed to cook and turned constantly to prevent any lump formation and burning. Another cassava fermented flour similar to fufu is efubo. It is a cassava fermented dry flour commonly consumed in the western states of Nigeria(Uzogara et al., 1990). The production involves peeling of cassava roots, washing and cutting into chunks. The chunks are soaked in water in pots or at edges of stream and left for three to four days to ferment and soften. At the end of fermentation the softened chunks are dried under the sun for 2 days, ground and sieved to produce 'efubo'(Uzogara et al., 1990). Kuboye and Ogunjobi (2016) put out another method of lafun production. It is involves soaking of cassava roots to ferment after which they are peeled, dewatered, sundried, milled and sieved to yield lafun (Wakil and Benjamin, 2015; Kuboye and Ogunjobi, 2016).

\section{Kokondé}

Kokondé is also known as Kokonte, Crueira or Alebo(Oyewole Olusola and Yemisi, 2003). It is an Ivorian originatescassava fermented food. Kokondé is prepared with fermented cassava ships. Then, cassava roots are first processed into fermented chips by peeling and soaked for hours. After grinding (optional), the pieces are washed and dried in the sun. Thatched roofs or sheet metal are used for drying. Drying may take several weeks depending on the state of the sunshine. The obtained fermented chips are crushed, ground and sieved into flour. The flour is cooked in a shooting paste. Kokondé 
is consumed with a sauce(Quintson, 2015; Jensen et al., 2015).

\section{Agbelima}

Agbelima is a popular cassava fermented food in Ghana and Côte d'Ivoire. It also used as raw material in the preparation of a wide range of traditional cassava meals including banku, akple and kenkey and can easily be produced in larger quantities at a relatively low cost (Ellis et al., 1997). The production of agbelima involves the use of atraditional inoculum, the kudeme. According to (Ellis et al., 1997; Nwankwo et al.)the main purpose for using this inoculum is for souring and improving the texture, color and flavor of the product. The cassava roots used for agbelima production are knife peeled and steeped in water for initial fermentation and then ground to paste(Amoa-Awua etal., 1996; Dziedzoave et al., 2000). The grated mash from obtained is inoculated with a proportional quantity of kudeme. The cassava paste is left to ferment for up to 2 days in polypropylene sackswithout the application of any external pressure on the sacks. The paste is then pressed. And the paste is removed from the sacks, crumbled or granulated, and then steamed(Rosales-Soto et al., 2016).

\section{Loi-loi}

Loi-loiis a kind of $f u f u$ which is popular among the Riverine States of Nigeria, especially Rivers, Cross River and Akwa Ibom States(Ray and Sivakumar, 2009). The processing varies but basically consists of hanging the product at the prevailing tropical climate as conditioning prior to preparation for final consumption or spreading in a thick heap to dry for one to five days. Fermentation takes place resulting in the development of a characteristic aroma. The preparation is thus: cassava roots are peeled, washed, and soaked for two days in water to partially soften and ferment them. The roots are then ground into a paste using the village mill. The paste is mixed with fresh cold water and left to ferment for a day. Sieving is carried out to obtain a crude starch suspension. This is put into a cloth bag and dewatered resulting in starch which can be dispersed in a little cold water and stirred into hot boiling water until a smooth paste is formed to produce prepared loiloi(Uzogara et al., 1990).

\section{Attoupkou}

Attoupkou is a popular food in the southeast of Côte d'Ivoire(Nevry et al., 2007; Yao et al., 2015). The cassava roots are first peeled and cut coarsely. The fibers are removed and then the tubers are washed and shredded to give cassava dough. The cassava dough obtained is fermented and drained during a night under stone bloks pressure. The fermented dough is sifted and dewatered using sieve to eliminate some of the fibers. A steaming in a steamer gives a sticky cake, the attoupkou which is then packaged(SoroYao et al., 2013)

\section{Dumby}

Dumby is a common traditional food in Liberia. The cassava's skin, coarse central fibers, and rind are removed and the boiled tubers are placed in a wooden mortar and beaten with a heavy pestle. As the mass becomes homogenous, the pestle produces a loud crack as it gets thicker. Dumby is normally eaten witha soup made from a variety of meat and vegetables(Raheem and Chukwuma, 2001). In Liberia, cassava is made into dumby, which is prepared by placing boiled cassava roots following pounding, the dumby is cut into pieces and put in soup supplemented with vegetables. The food is used to feed children because of its high protein content(Balagopalan, 2002b). 


\section{Abacha}

Abacha or Akpu-mmiri refers to wet cassava chips consumed as a popular snack in southeastern Nigeria. To prepare abacha, the cassava root tubers are washed, peeled, boiled in water for about $1 \mathrm{~h}$ and cut into longitudinal slices or chips. These chips are steeped in water for 1-2 days during which the water may be changed once or twice. At the end of the fermentation (during which the taste of the chips becomes almost bland), the chips are finally washed two or three times with fresh cold water(Uzogara et al., 1990; Iwuoha and Eke, 1996). An alternative handling for long term storage is to dry the chips under the sun for several days(Balagopalan, 2002a).

\section{Kapok pogari}

Kapok pogari is a mid-western Nigerian food is similar to gariin preparation. The only difference is that the grated and fermented mass is not sieved before roasting. The resultant product has bigger particles. Kapok pogariis consumed with fish, coconut or meat (Balagopalan, 2002a; Soro-Yao et al., 2013).

\section{Bêêekouma}

Bêdêkouman is a cassava fermented food family located in Côte d'Ivoire. It production is mainly located among Aboure N'zima ethnic group in the Southeast part of the country. It is a white bread as food with 10 to $15 \mathrm{~cm}$ as size packeted in Tomatococcus danielli leaves localy called “attiéké leaves"(Aboua, 1988). Bêdêkouman can be stored at room temperature for 4 days (Koffi-Nevry et al., 2005). To produce bêdekouman the fermented cassava mash is cooked, shelled and shaped into Tomatococcus danielli. It is eaten with vegetables, fish or meat.
Microorganisms associates with cassava fermented food in Africa

Several microorganisms are involved in cassava fermented foods fermentation. It include lactic acid bacteria, Bacillus strains, yeasts, moulds and some others organisms. The main microorganisms associates in cassava food fermentation are as shown in table I.

\section{Biochemical compound produce during cassava food fermentation}

\section{Volatiles organic compounds}

The change in aroma as volatiles and flavour compounds found in African cassava fermented based food includethese molecules (Carvacrol (McFeeters, 2004; Damasceno etal., 2003; Schwan et al., 2014; Corral et al., 2015; Morales et al., 2003; Muyanja et al., 2012; Onyango et al., 2004; Dhellot et al., 2014; Djeni et al., 2015; Lasekan et al., 2016):

Aldehydes: Propanal , 2-Methylpropanal, Butanal , 3-Methylbutanal, 2-Methybutanal, Pentanal, 2-Pentenal, Hexanal, 2-Hexenal, Heptanal, 2,4-Hexadienal, 2-Heptenal, Benzaldehyde, Octanal, 2,4-Heptadienal, Furfuryl, 1,3 butanediol,Ethyl acetate, Isobutyl acetate, Phenylethyl acetate, Benzene acetaldehyde, 2-Octenal, 2acetylpyrroline, Nonanal, 2-Nonenal , 2,4Nonadienal, (2Z)-2-phenyl-2-butenal, 2,4Decadienal; Alcohol: 1-Butanol, (isoamilic alcohol), 2-methyl 1 butanol, Phenylethanol, Ethanol, 3-Methyl-1-butanol, 1-Pentanol, 1Hexanol;

Alkanes: Pentane, Hexane, Heptane, Octane, 2-Octene, Decane, Dodecane , Tridecane, Tetradecane;

Ketones: Acetone, 2,3-Butanedione, 2- 
Butanone, 3-Methyl-2-butanone, 2Pentanone, 2,3-Pentanedione, 3-Hydroxy-2butanone, 2-Heptanone , 3-Octen-2-one , 1octen-3-one, 2-Nonanone, L-carvone, Undecanone, Mrthyl nonylcetone, Piperitone, L-carvone, Iso-menthone, Menthone;

Nitrogen compounds: Pyridine, 2Ethylpyridine, 2,5-Dimethylpyrazine , Trimethylpirazine, Tetramethylpyrazine , 1Piperidinecarboxaldehyde Ethyl 3pyridinecarboxylate; Terpenes, $\alpha$-Terpeniol, $\beta$-Citronellol, Guaiacol, 1-3 Butanodiol ; Others : Myrcene, Limonene, eucalyptol, para-cymene, beta ocimene, $\beta$ beta ocimene, Gamma terpinene, 2,Terpinen-4-ol, Methyl salicylate, Estragol, Methyl thymol ether, Lcarvone, , Citronnellyl formiate .

\section{Organic acids}

The microorganisms involved in cassava fermentation have homolactic and heterolactic activities. The process of organic acids production necessitates the initial breakdown of starch to sugars before these sugars are fermented by both moulds, lactic bacteria.

The main organic acid synthetize by bacteria during cassava fermentation are butyric acid, Hexanoic acid, Octanoic acid, Decanoic acid, Nonanoic acid, Dehydro acetic acid, 2Methyl propanoic, Oxalic, Citric, Tartaric, Mallic, Ascorbic, Lactic, Acetic, Fumaric, Propionic, Carboxylic acids, Hexanoic, Octanoic, Nonanoic (McFeeters, 2004; Damasceno etal., 2003; Schwan et al., 2014; Corral et al., 2015; Morales et al., 2003; Muyanja et al., 2012; Onyango et al., 2004; Dhellot et al., 2014; Djeni et al., 2015; Lasekan et al., 2016).

\section{Vitamins}

Folates or vitamin B9 are the essential cofactors in the biosynthesis of nucleotides.
There are therefore crucial for the cellular replication and growth. Plants, yeast and some bacterial species in fermented food contain the folate biosynthesis pathway and produce natural folates. But mammals lack the ability to synthesize folate and they are therefore dependent on sufficient intake from diet(Gregory, 1989; Patring et al., 2005; Moslehi-Jenabian et al., 2010). Several lactic acid bacteria and yeast have been identified to synthetize folates (vitamin B9) in different medium. Among them, some have been isolate in cassava fermented by products. It is the case of Lactobacillus rhamnosus, Lactobacillus plantarum, Lactobacillus acidophilus, Lactobacillus reuteri, E. faecium, Lactobacillus fermentum, Lactobacillus brevis, Lactobacillus salivaris, $S$. cerevisiae (LeBlanc et al., 2007; Chelule et al., 2010; Hasan et al., 2014; Anyogu et al., 2014). The proper selection of probiotic folate producing strains provides is then a strategy for the development of novel functional cassava fermented foods with increased nutritional value(Gregory, 1989).

\section{Role and function of fermentation on cassava food}

Fermentation is a metabolic process converting carbohydrates to organics acids. It is a food technology used some centuries. It is appreciate for it many advantages in food science. Fermentation can increase protein and vitamins content and improve the balance of essential amino acids. Fermentation increase also the volatiles organic content and reduce anti-nutrients content.

\section{Aroma and flavor change}

Fermentation makes the cassava fermented food palatable by enhancing its aroma and flavor. These organoleptic properties make 
fermented food more popular than the unfermented one in terms of consumer acceptance. Furthermore, food acidification does not result in improvement of food texture and quality(Chelule et al., 2010). Then, fermentation is unique in that it modifies the unfermented food in diverse ways, resulting in new sensory properties in the fermented product. However, not all bacteria and moulds are beneficial in enhancing food flavor. The aroma and flavour compound found in African cassava fermented based food include aldehydes; organic acids, alcohol, alkanes, terpenes, ketones, nitrogen compounds, and some others compound(McFeeters, 2004; Damasceno et al., 2003; Schwan et al., 2014; Corral et al., 2015; Morales et al., 2003; Muyanja et al., 2012; Onyango et al., 2004; Dhellot et al., 2014; Djeni et al., 2015; Lasekan et al., 2016). The aroma and flavor compound depend on the involved microorganisms in the fermentation. In some instances, they may cause food spoilage since their enzymes may lead to generation of fermentation digests that have offensive odours or flavours, making food to be entirely unpalatable

\section{Physical and biological properties}

Many operation units of the fermentation procedures involve steeping tubers in water for long periods. In a number of cases, the dry matter had decreased. The decrease can attribute to a partly reduction in sugar and starch and the leaking of soluble constituents. In addition, the softening of the tubers may be leading to increased absorption of water, contributing to the reduction in dry weight. During the soaking of roots in cassava food production, the texture of the roots undergoes noticeable change and the roots are rendered soft. The fibers content in the fermenting tubers rose with the time of fermentation and the effect is uniform with all varities of cassava. Fibers content increase is due to the action of pectinolytic and cellulolytic enzymes produced by the fermenting microorganisms, which break down cell membranes (Aloys and Angeline, 2009; Aloys and Hui Ming, 2006; Aloys and Zhou, 2006b).

\section{Cassava fermented food preservation}

The preservative activity of lactic acid bacteria and others associate microorganisms in some cassava fermented product in one of the main reason of it fermentation. It is a alternative issue for cassava food storage in poor communities in African countries. During cassava fermentation process, some biochemical compound like organic acids, aldehydes, alcohol, hydrogen peroxide, carbon dioxide are produce(Schwan . et al., 2014; Corral . et al., 2015; Lasekan et al., 2016). The antagonism of lactic acid bacteria against pathogenic or other bacteria is believed to result from the action of the acids on the bacterial cytoplasmic membrane which interferes with the maintenance of membrane potential and inhibits active transport and may be mediated both by dissociated and undissociated acid (Cherrington et al., 1991). The antimicrobial activity of each of them is not correlate with it molar concentration. It can inhibit yeasts, moulds and bacteria (Blom and Mørtvedt, 1991). Propionic acid inhibits fungi and bacteria. The contribution of aldehyde to flavour is more than it bio preservative properties. Hydrogen peroxide accumulate can be inhibitory to some microorganisms (Condon, 1987). This inhibition is mediated through the strong oxidising effect on membrane lipids and cell proteins (Castberg and Morris, 1976). Carbon dioxide, formed during heterolactic fermentation, can directly create an anaerobic environment 
and is toxic to some aerobic food microorganisms through it action on cell membranes and its ability to reduce internal and external $\mathrm{pH}$. With these properties, associate microorganisms contribute to inhibit both pathogen and no pathogen microorganism growth in cassava fermented food (Cooke et al., 1987; Caplice and Fitzgerald, 1999; Ross et al., 2002). They then contribute to it bio preservation. In addition, some associate fungi can reduce considerably toxins content in food.

\section{Functional properties of starch}

Functional properties of starch extracted from fermented tubers and that were subjected to fermentation are invariably modified by fermentation. Baking testsusing sweet, fermented (20 to 30 days) and acidtreated starches showed that sour starch provided a baked product with excellent volume, alveolar loose crumb structure, and a thin crispy crust(Bertolini et al., 2001). The textural properties of starch gels from naturally fermented and inoculum provided showed that the hardness, gumminess, and elasticity of the flour gels were reduced in fermented products. Gel hardness and gumminess have been associated both to the degree of granule swelling and network formation by leached amylose. A reduction in cohesiveness of fermented products has been explained as due to failure of starch granules to release sufficient amylose. The improvement in textural quality also has been attributed to the production of organic acids that complex withthe soluble amylose portion (Mestres et al., 2000). Studies on the functional properties of the sour cassava starch, revealed that the chemical composition was not significantly modified by the fermentation step, whereas the granular structure was similar to that resulting from a short period of mild acid treatment (Camargo et al., 1988). The released $\mathrm{CO} 2$, lactic acid, and propionic acid during the fermentation step of sour cassava production were assumed to have absorbed to the granular starches and their desorption during cooking would be an additional driving force for the expansion of the resultantproduct. It further was suggested that water vaporization also might perform the same role(Aloys and Angeline, 2009; Aloys and Zhou, 2006b).

\section{Antinutrient decrease in cassava fermented food}

Phytates and tannins are important antinutritional compound found in cassava roots and leaves as in other tubers, roots and legume use by plant for defense. Phytates (inositol hexakisphosphate) compound is in high abundance in cassava, with approximately $624 \mathrm{mg} / 100 \mathrm{~g}$ in roots (Marfo et al., 1990). Phytic acid is able to bind cations such as magnesium, calcium, iron, zinc, and molybdenum and can, therefore, interfere with mineral absorption and utilization (Hambidge et al., 2008). Phytic acid may also bind proteins preventing their complete enzymatic digestion. However, phytic acids also have antioxidant and anticarcinogenic proper ties. Indeed, phytic acids can reduce free ion radical generation and thus peroxidation of membranes by complexing iron, and phytate may protect against colon cancer. Phytate was able to reduce serum cholesterol and triglycerides in an animal model fed a cholesterol-enriched diet (Kumar et al., 2010). Tannins affect the nutritive value of food products by forming a complex with protein (both substrate and enzyme) thereby inhibiting digestion and absorption. They also bind Fe, making it unavailable and recent evidence suggests that condensed tannins may cleave DNA in the presence of copper ions (Aletor, 1993). It then increases malnutrition status of people who have it as mainly food. 
Fermentation is one the processes use to reduce tannin and phytate content in cassava roots and leaves. Fermentation was found to reduce the phytate levels to a large extent. The fermentation time effect on phytate and tannin reduction is also evident. Their content in fermented food depends on the fermentation techniques used. The reduction of the phytate content level in cassava fermented food is due to enzymatic activity. This enzyme may be naturally present in cassava (Aloys and Hui Ming, 2006) or secreted by involved microorganisms. The enzyme is able to hydrolyze phytate in the medium and the reduce phytate content cassava fermented food. The reduction of phytate is more significant after 24 to $48 \mathrm{~h}$ of fermentation and decrease after 48h (Marfo et al., 1990). The drop of $\mathrm{pH}$ probably contributes to the slow breakdown of the phytate after $48 \mathrm{~h}$ of fermentation. Ranhotra et al., (suggested that inorganic phosphate might contribute to the inhibition of phytase enzyme activity in fermented doughs. Fermentation also has been foundto be effective in reducing tannin, the other important anti-nutritive factor in cassava. Emmanuel and al., (2004) found a reduction of phytate content in fermented dough ranged from $20 \%$ to $67 \%$. But some other operations units and processes may have effect on the phytate reduction. Emmmanuel and al, (2004) found a reduction level of total phytate in raw tuber of $88.78 \%$ in gari from cassava, $95.19 \%$ in eba from cassava gari, $68.59 \%$ in ampesi from cassava and 69.87 in fufu from cassava.Ganiyu (2002) found a decrease of 705.1-789.7 mg/100g of total phytate content in cassava peels. Oboh et al., (2002) found significant reduction of tannin content in cassava fermented food such as gari and flour. The tannin contents of the Aspergillus nigerfermented cassava flour and gari(Coulin et al., 2006) are considerably low when compared to the usual level of tannin in cassava tubers $(0.4$
0.5\%) (Hahn, 1992) and compared favourably with tannin content of Rhizopus oryzae-fermented flourWakil and al., (2015) found a significant reduction of tannin, cyanide, phytate and oxalate in pupuru, a cassava fermented food in West Africa, using a starter culture of Lactobacillus plantarun and Candida famata. Pupuru had at least Tannin, cyanide, phytate and oxalate content of $0.05 \mathrm{mg} / 100 \mathrm{~g}, 0.24 \mathrm{mg} / 100 \mathrm{~g}$, $102.4 \mathrm{mg} / 100 \mathrm{~g}$ and $2.94 \mathrm{mg} / 100 \mathrm{~g}$ respectively (Wakil et al., 2015). Olaoye and al., 2015 also found antinutritional factor $(\mathrm{mg} / 100 \mathrm{~g})$, tannin, phytate, oxalate and trypsin inhibitor reduced from 0.59 , 301.21, 46.23 and 7.02 at $0 \mathrm{~h}$ to $0.41,64.38$, 13.56 and 1.52 at $120 \mathrm{~h}$ respectively in the NR8082 cassava gari samples.

\section{Cyanide reduction in cassava fermented food}

Cyanide is the most toxic factor restricting the consumption of cassava roots and leaves (Montagnac et al., 2009). The cyanide content of some cassava varieties, particularly the bitter one is more than $10 \mathrm{mg}$ cyanide equivalents/kg DM, the FAO/WHO. The cyanide content of cassava leaves is highest than in cassava root and it ranged from 53 to $1300 \mathrm{mg}$ equivalents $/ \mathrm{kg} \mathrm{DM}$. Cyanide is cause of acute toxicity in humans. Residual cyanogens content in processed cassava, which exist as glucoside, cyanohydrin or free cyanide, which are equally toxic as their parent compounds in uncooked food Several methods are used for cassava detoxification including peeling, grating, soaking, boiling/cooking, ensiling, drying, fermentation (Teweet al.,1989; Okeet al., 1994; Lambriet al., 2013; Kyawt and al., 2014). 
Int.J.Curr.Microbiol.App.Sci (2016) 5(10): 664-687

Table.1 Associates microorganisms in cassava mainly fermented food in Africa

\begin{tabular}{|c|c|c|c|c|c|}
\hline $\begin{array}{l}\text { Cassava } \\
\text { fermented } \\
\text { food }\end{array}$ & $\begin{array}{l}\text { Lactic acid bacteria and others } \\
\text { bacteria }\end{array}$ & Yeast & Moulds & $\begin{array}{c}\text { Mainly Region } \\
\text { or country of } \\
\text { production }\end{array}$ & References \\
\hline \multirow{11}{*}{ Gari } & Bacillus subtilis ; Bacillus & Saccharomyces fragilis ; & & \multirow{11}{*}{$\begin{array}{l}\text { West, Central } \\
\text { and East Africa } \\
\text { countries }\end{array}$} & \multirow{11}{*}{$\begin{array}{c}\text { (OKAFOR, 1977; } \\
\text { Ngaba and Lee, } \\
\text { 1979; Moorthy } \\
\text { and Mathew, } \\
\text { 1998) }\end{array}$} \\
\hline & coagulan ; Bacillus species;, & Saccharomyces serevisae; & & & \\
\hline & Lactobacillus brevis ; & & & & \\
\hline & Lactobacillus pentosus & & & & \\
\hline & Lactobacillus acidophilus ; & & & & \\
\hline & Lactobacillus sp ; Leuconostoc, & & & & \\
\hline & Corunebacterium species, & & & & \\
\hline & Pseudomonas mesenteroides, & & & & \\
\hline & Weissella paramesenteroides; & & & & \\
\hline & Corynebacterium; Bacteriodes & & & & \\
\hline & sp; Actinomyces sp & & & & \\
\hline
\end{tabular}




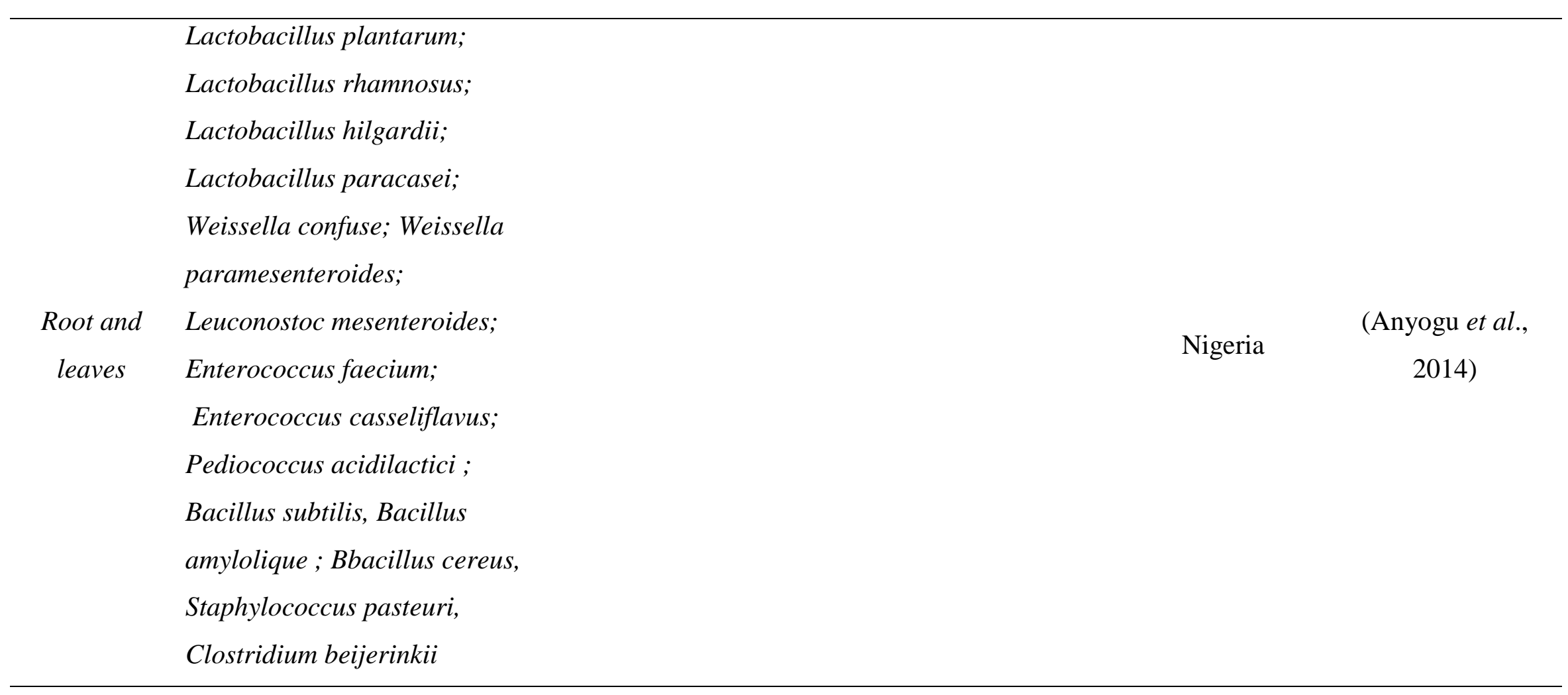

Lactococcus lactis; Leuconostoc

$\begin{array}{clcc}\text { Chikwangue } & \text { sp; Lactococcus plantarum; } & & \text { Main central } \\ & \text { Lactobacillus plantarum; } & \text { Africa countries } & \text { (Keleke, 1996) } \\ & \text { Clostridium spp. } & & \text { Main west and (Moorthy and } \\ \text { Fufu } & \text { Lactobacillus plantarum; } & \text { Saccharomyces cerevisiae, } & \text { central Africa Mathew, 1998) }\end{array}$


Streptococcus faecalis;

countries

Escherichia coli

\begin{tabular}{|c|c|c|c|c|}
\hline \multirow{13}{*}{ Lafun } & Klebsiella pneumonia; & Pichia scutulata; Pichia & \multirow{13}{*}{$\begin{array}{c}\text { Main west } \\
\text { Africa countries }\end{array}$} & \multirow[b]{5}{*}{ (Moorthy and } \\
\hline & Pantoea gglomerans; & kudriavzevii ; Pichia & & \\
\hline & Lactobacillus fermentum; & rhodanensis; Pichia & & \\
\hline & Lactobacillus plantarum; & scutulata; Candida & & \\
\hline & Weissella confuse; & glabrata ; & & \\
\hline & Corynebacterium sp; & Candida tropicalis & & Mathew, 1998; \\
\hline & Lactobacillus sp,;Streptococcus & Hanseniaspora & & Ijabadeniyi, 2007; \\
\hline & $s p . ;$ & guilliermondii ; & & Padonou et al., \\
\hline & Pseudomonas sp.;Listeria sp; & Trichosporon asahii, & & 2009) \\
\hline & Corynebacterium sp.; & Saccharomyces cerevisiae; & & \\
\hline & Bacillus cereus; Klebsiella & Kluyveromyces marxianus; & & \\
\hline & pneumonia; & Hanseniaspora & & \\
\hline & Pantoea agglomerans & guilliermondii; & & \\
\hline \multirow{2}{*}{ Ogiri } & Lactobacillus sp., Streptococcus & & \multirow{2}{*}{ Nigeria } & (Ijabadeniyi, \\
\hline & sp., Pediococcus sp., Bacillus sp & & & 2007) \\
\hline \multirow{2}{*}{ Attiéké } & Lactobacillus plantarum; & Candida sp, Candida & Côte d'Ivoire, & (Assanvo et al., \\
\hline & Lactobacillus; fermentum; & valida; Candida holmii; & Burkina Faso, & 2002; Djeni et al., \\
\hline
\end{tabular}




\begin{tabular}{|c|c|c|c|c|c|}
\hline & $\begin{array}{l}\text { Lactobacillus cellobiosus; } \\
\text { Lactobacillus brevis; } \\
\text { Leuconostoc mesenteroides, } \\
\text { Pediococcus acidilactici, } \\
\text { Weissella cibaria; Lactobacillus } \\
\text { sp; Bacillus sp, Bacillus } \\
\text { sphaericus; Bacillus brevis, } \\
\text { Bacillus; coangulans, } \\
\text { Enterococcus faecium }\end{array}$ & $\begin{array}{l}\text { Candida krusei; Kloeckera } \\
\text { japonica; Saccharomyces } \\
\text { cerevisiae }\end{array}$ & & $\begin{array}{l}\text { Bénin, Mali, } \\
\text { Sénégal, Togo }\end{array}$ & 2015) \\
\hline Ikivunde & $\begin{array}{l}\text { Lactobacillus plantarum; } \\
\text { Lactobacillus brevis; } \\
\text { Lactobacillus fermentum; } \\
\text { Leuconostoc mesenteroides }\end{array}$ & Geotrichum candidum & & $\begin{array}{l}\text { Burundi, } \\
\text { Rwanda }\end{array}$ & $\begin{array}{c}\text { (Aloys and } \\
\text { Angeline, 2009) }\end{array}$ \\
\hline Iyanye & & & $\begin{array}{l}\text { Aspergillus } \\
\text { oryzae; } \\
\text { Aspergillus } \\
\text { fumigatus; } \\
\text { Penicillium } \\
\text { citrinum; } \\
\text { Penicillium }\end{array}$ & Burundi & $\begin{array}{c}\text { (Hahn, 1989; } \\
\text { Musuku, 1995; } \\
\text { Rwamudanga, } \\
\text { 1988; Aloys and } \\
\text { Hui Ming, 2006) }\end{array}$ \\
\hline
\end{tabular}




\begin{tabular}{|c|c|c|c|c|c|}
\hline & & & $\begin{array}{l}\text { chrysogenum; } \\
\text { Rhizopus } \\
\text { stolonifera; } \\
\text { Mucor spp }\end{array}$ & & \\
\hline Agbelima & $\begin{array}{l}\text { Lactobacillus brevis; } \\
\text { Lactobacillus plantarum; } \\
\text { Lactobacillus salivarius; } \\
\text { Lactobacillus fermentum; } \\
\text { Leuconostoc mesenteroides; } \\
\text { Bacillus subtilis ; Bacillus spp; }\end{array}$ & $\begin{array}{l}\text { Candida tropicalis; } \\
\text { Candida krusei; } \\
\text { Zygosaccharomyces spp; } \\
\text { Zygosaccharomyces bailii; } \\
\text { Geatrichum candidum; } \\
\text { Rhizopus spp; }\end{array}$ & $\begin{array}{l}\text { Penicillium } \\
\text { selectiorum } \\
\text { Penicillium } \\
\text { citrinum; } \\
\text { Penicillium } \\
\text { nodulum; }\end{array}$ & $\begin{array}{l}\text { Côte d'Ivoire, } \\
\text { Ghana, Togo }\end{array}$ & $\begin{array}{l}\text { (Amoa-Awua et } \\
\text { al., 1996; } \\
\text { Dziedzoave } \text { et al., } \\
\text { 1999; Mante et } \\
\text { al., 2003; Padonou } \\
\text { et al., 2009) }\end{array}$ \\
\hline Akeyke & $\begin{array}{l}\text { Lactobacillus plantarum; } \\
\text { Lactobacillus salivarius; } \\
\text { Lactobacillus brevis ; } \\
\text { Lactobacillus fermentum; } \\
\text { Leuconostoc mesenteroides ; } \\
\text { Bacillus subtilis; Bacillus } \\
\text { lichniferomis; Bacillus cereus; } \\
\text { Bacillus pumilis ; } \\
\text { Corynebacterium Spp }\end{array}$ & $\begin{array}{l}\text { Zygosaccharomyces } \\
\text { florentinus;Candida } \\
\text { krusei ;Geotrichum } \\
\text { candidum;Candida } \\
\text { tropicalis }\end{array}$ & & Ghana & $\begin{array}{c}\text { (Obilie et al., } \\
\text { 2004) }\end{array}$ \\
\hline
\end{tabular}


Fermentation is one of the most used methods in food processing. It reduces significantly cyanide content in cassava fermented food, to improve flavour and aroma of fermented food and contribute to bio-preservation of fermented food. The cyanide reduction trough fermentation is due to the enzymatic activity of the associate microorganisms in cassava fermentation. The reduction level then varies according to the fermentation time and also to the microorganisms' species in the fermentation medium. According to Essers et al., (1994) Neurospora sitophila and Geotrichum candidum did not hydrolyse appreciable amounts of linamarin, while Bacillus $s p$.hydrolysed virtually all. And Mucor racemosus had hydrolysed at least $90 \%$ of linamarin and Rhizopus oryzae 45 to $84 \%$. Kimayoro et al., (2000) (Kimaryo et al.,) quantified $\alpha$-glucosidase activity ranged between 20 and $\geq 40 \mathrm{nmol} / 4 \mathrm{~h}$ for Lactobacillus plantarun, used as strarter for cassava fermentation. And Darman and got and cyanide reduction of $95 \%$ during cassava fermentation using Lactobacillus sp., Saccharomyces sp., and Rhyzopus sp as starter culture. Olaoye and al., Wakil and al., found a few level of residual content of cyanide of 0.24 and $126.83 \mathrm{mg} / 100 \mathrm{~g}$ respectively in pupuru and gari. The fermentation techniques used has an impact on the cyanide reduction (Tewe and al., 1989; Ahaotu et al., 2013). Fayemiet al., (2013) found a cyanide content of 15.67, 13.29 and $12.67 \mathrm{mg} / \mathrm{kg}$ of fufu using the traditional, brine and backsloppingfermentation of respectively. The other cassava fermented foods have a significant reduction of their cyanide content compare with cassava root, as raw materials. Burns et al., (1990) found a cyanide content of tapioca crips and tapioca flour of 42 and $<1 \mathrm{mg} / \mathrm{kg}$ respectively while Heuberger (2005) found a cyanide levels $49 \mathrm{mg} / \mathrm{kg}$ in placali, $50 \mathrm{mg} / \mathrm{kg}$ in foufou manioc, 3.1 $\mathrm{mg} / \mathrm{kg}$ in boule de manioc. The reduction levels was $50 \%$ in attiéké and $30 \%$ in attiéké garba (Heuberger, 2005). But a production assay in laboratory condition leads to a cyanide level of $0.1 \mathrm{mg} / \mathrm{kg}$ and $0 \mathrm{mg} / \mathrm{kg}$ respectively in attiéké and attéiéké garba. Amoa-Awua got a cyanide reduction level of $60.2 \%$ and Obilé et al., (2004) obtained a cyanide reduction of $98 \%$.

In conclusion, African communities have developed several processes for cassava dried food production. The cassava fermented foods are sometime similar except the varieties and ingredients are different. There is diversity in associate microorganisms in cassava fermentation. These microorganisms contribute a lot in cassava fermented food flavor, aroma, antinutrients and cyanide content decrease. The fermentation processes in the main factor of cassava fermented food preservation.

\section{References}

Aboua, F. 1988. Preparacion tradicionnal de alimentas con yuca en Costa de Marfil. Yuca Buletin Informativo, 12: 10-12.

Adeniran, H. and Ajifolokun, O. 2015. Microbiological studies and sensory evaluation of breadfruit and cassava cofermented into gari analogue. Nigerian Food J., 33: 39-47.

Aletor, V. 1993. Allelochemicals in plant foods and feedingstuffs: 1. Nutritional, biochemical and physiopathological aspects in animal production. Vet. Human Toxicol., 35: 57-67.

Aloys, N. and Angeline, N. 2009. Traditional fermented foods and beverages in Burundi. Food Res. Int., 42: 588-594.

Aloys, N. and Hui Ming, Z. 2006. Traditional cassava foods in Burundi-A review. Food Reviews Int., 22: 1-27.

Aloys, N. and Zhou, H.M. 2006a. Comparative study on nutrient and anti- nutrient 
changes in Ikivunde and Inyange, two Burundian traditionally processed cassava products. J. Sci. Food and Agri., 86: 1878-1886.

Aloys, N. and Zhou, H.M. 2006b. Functional and chemical properties of Ikivunde and Inyange, two traditionally processed Burundian cassava flours. J. Food Biochem., 30: 429-443.

Amey, M. 1987. Some traditional methods of Cassava conservation and processing in Uganda Paper presented at the Third East and Southern Africa Crops Workshop, 711 December 1987. Mzuzu, Malawi.

Amoa-Awua, W.K.A., Appoh, F.E. and Jakobsen, M. 1996. Lactic acid fermentation of cassava dough into agbelima. Int. J. Food Microbiol., 31: 8798.

Anukam, K.C. and Reid, G. 2009. African traditional fermented foods and probiotics. J. Med. Food, 12: 1177-1184.

Anyogu, A., Awamaria, B., Sutherland, J., et al. 2014. Molecular characterisation and antimicrobial activity of bacteria associated with submerged lactic acid cassava fermentation. Food Control, 39: 119-127.

Assanvo, J., Agbo, G., Behi, Y., et al. 2002. La microflore du ferment de manioc pour la production de l'attiéké adjoukrou à Dabou (Côte d'Ivoire). Bioterre, Rev. Inter. Sci. de la Vie et de la Terre: 27-29.

Assanvo, J., Agbo, G., Behi, Y., et al. 2006. Microflora of traditional starter made from cassava for "attiéké" production in Dabou (Côte d'Ivoire). Food control, 17: 37-41.

Balagopalan, C. 2002a. Cassava Utilization in Food, Feed and Industry. In: R. J. Hillocks JMT, Anthony Bellotti (ed) Cassava: Biology, Production and Utilization.

Balagopalan, C. 2002b. Cassava utilization in food, feed and industry. Cassava:
Biology, production and utilization: 301318.

Bamidele, O.P., Fasogbon, M.B., Oladiran, D.A., et al. 2015. Nutritional composition of fufu analog flour produced from Cassava root (Manihot esculenta) and Cocoyam (Colocasia esculenta) tuber. Food science \& nutrition 3: 597-603.

Bertolini, A., Mestres, C., Colonna, P., et al. 2001. Free radical formation in UV-and gamma-irradiated cassava starch. Carbohydrate Polymers 44: 269-271.

Blench, R. 2014. The diffusion of cassava in Africa: lexical and other evidence. 45.

Blom, H. and Mørtvedt, C. 1991. Antimicrobial substances produced by food associated micro-organisms. Biochemical Society Transactions 19: 694-698.

Bull, S. 2011. Study of post-harvest physiological deterioration in transgenic cassava. University of Bath.

Camargo, C., Colonna, P., Buleon, A., et al. 1988. Functional properties of sour cassava (Manihot utilissima) starch: polvilho azedo. J. Sci. Food and Agri., 45: 273-289.

Caplice, E. and Fitzgerald, G.F. 1999. Food fermentations: role of microorganisms in food production and preservation. Int. J. Food Microbiol., 50: 131-149.

Castberg, H. and Morris, H. 1976. Degradation of milk proteins by enzymes from lactic acid bacteria used in cheese making. A review. Milchwissenschaft.

Chelule, P., Mokoena, M. and Gqaleni, N. 2010. Advantages of traditional lactic acid bacteria fermentation of food in Africa. Curr. Res. Technol. Education Topics In Appl. Microbiol. Microbial Biotechnol., 2: 1160-1167.

Cherrington, C., Hinton, M., Mead, G, et al. 1991. Organic acids: chemistry, antibacterial activity and practical applications. Adv. microbial physiol., 32: 87-108. 
Condon, S. 1987. Responses of lactic acid bacteria to oxygen. FEMS Microbiol. Rev., 3: 269-280.

Cooke, R.D., Twiddy, D.R. and Reilly, P.A. 1987. Lactic-acid fermentation as a lowcost means of food preservation in tropical countries. FEMS Microbiol. Rev., 3: 369-379.

Corral, S., Salvador, A. and Flores, M. 2015. Elucidation of key aroma compounds in traditional dry fermented sausages using different extraction techniques. J. Sci. Food and Agri., 95: 1350-1361.

Coulin, P., Farah, Z., Assanvo, J., et al. 2006. Characterisation of the microflora of attieke, a fermented cassava product, during traditional small-scale preparation. Int. J. Food Microbiol., 106: 131-136.

Damasceno, S., Cereda, M., Pastore, G., et al. 2003. Production of volatile compounds by Geotrichum fragrans using cassava wastewater as substrate. Process Biochem., 39: 411-414.

Dhellot, J., Mokemiabeka, S., Moyen, R., et al. 2014. Volatile compounds produced in two traditional fermented foods of the Congo: Nsamba (palm wine) and bikedi (retted cassava dough). African $J$. Biotechnol., 13.

Djeni, N., Bouatenin, K.P., Assohoun, N., et al. 2015. Biochemical and microbial characterization of cassava inocula from the three main attieke production zones in Côte d'Ivoire. Food Control, 50: 133-140.

Djeni, N., N'guessan, K., Toka, D., et al. 2011. Quality of attieke (a fermented cassava product) from the three main processing zones in Côte d'Ivoire. Food Res. Int., 44: 410-416.

Djéni, T.N., Kouamé, A.K., Bouatenin, J.P.K., et al. 2014. Process of attieke production in Côte d'Ivoire: new trends, updates and effects on quality and preference of the food. Int. J., 2: 644-653.

Dziedzoave, N., Ellis, W., Oldham, J., et al. 2000. Optimizing agbelima production: varietal and fermentation effect on product quality. Food Res. Int., 33: 867873.

Dziedzoave, N., Ellis, W., Oldham, J., et al. 1999. Subjective and objective assessment ofagbelima'(cassava dough) quality. Food Control, 10: 63-67.

Ellis, W., Dziedzoave, N., Boakye, K., et al. 1997. Effect of cassava variety and processing methods on the performance of 'kudeme'in agbelima production. Food Control, 8: 199-204.

Enitan, F.O. 2010. Influence of Socioeconomic Characteristics on Use of Modern Cassava Processing Technologies among Women Processors in Ogun State, Nigeria. J. Social Sci., 24: 43-50.

Firmin, A. 1995. Optimization of traditional fermentation of cassava. Trop. Sci., 35: 68-75.

Flibert, G., Donatien, K., Hagrétou, S.L., et al. 2016. Hygienic Quality and Nutritional Value of Attiéké from Local and Imported Cassava Dough Produced with Different Traditional Starters in Burkina Faso. Food and Nutrition Sci., 7: 555.

Gregory, J.F. 1989. Chemical and nutritional aspects of folate research: analytical procedures, methods of folate synthesis, stability, and bioavailability of dietary folates. Adv. Food And Nutri. Res., 33: 1101.

Guira, F., Some, K., Kabore, D., et al. 2016. Origins, production, and utilization of cassava in Burkina Faso, a contribution of a neglected crop to household food security. Food Sci. Nutrition.

Hahn, S. 1989. An overview of African traditional cassava processing and utilization. Outlook on Agri., 18: 110118.

Hahn, S. 1992. An overview of traditional processing and utilization of cassava in Africa. Cassava as Livestock Feed in Africa: Proceedings of the 
IITA/ILCA/University of Ibadan Workshop on the Potential Utilization of Cassava as Livestock Feed in Africa: 1418 November 1988, Ibadan, Nigeria. IITA, 16.

Hambidge, K.M., Miller, L.V., Westcott, J.E., et al. 2008. Dietary reference intakes for zinc may require adjustment for phytate intake based upon model predictions. The J. nutrition 138: 2363-2366.

Hasan, M,. Sultan, M. and Mar-E-Um, M. 2014. Significance of fermented food in nutrition and food science. J. Scientific Res., 6: 373-386.

Heuberger, C. 2005. Cyanide content of cassava and fermented products with focus on attieke and attieke garba. Diss. 21.

Ijabadeniyi, A. 2007. Microbiological safety of gari, lafun and ogiri in Akure metropolis, Nigeria. African J. Biotechnol., 6.

Iwuoha, C.I. and Eke, O.S. 1996. Nigerian indigenous fermented foods: their traditional process operation, inherent problems, improvements and current status. Food Res. Int., 29: 527-540.

Jensen, S., Skibsted, L.H., Kidmose, U., et al. 2015. Addition of cassava flours in bread-making: sensory and textural evaluation. LWT-Food Sci. Technol., 60: 292-299.

Keleke, S. 1996. Le rouissage du manioc: contribution à l'étude du phénomène de ramollissement des racines de manioc.

Kimaryo, V., Massawe, G., Olasupo, N., et al. 2000. The use of a starter culture in the fermentation of cassava for the production of "kivunde", a traditional Tanzanian food product. Int. J. Food Microbiol., 56: 179-190.

Koffi-Nevry, R., Koussemon, M., Nanga, Z..Y, et al. 2005. Evolution de la microflore et caractéristiques physico-chimiques d'un aliment traditionnel à base de manioc (Manihot esculenta Crantz) fermenté: Le
Bêdêcouman. Editorial Advisory Board e 21: 259-267.

Kouamé, A.C., Kouassi, K.N. and N'dri, Y.D. 2015. Glycaemic index and load values tested in normoglycemic adults for five staple foodstuffs: Pounded Yam, Pounded Cassava-Plantain, Placali, Attieke and Maize Meal Stiff Porridge. Nutrients, 7: 1267-1281.

Kuboye, B. and Ogunjobi, S. 2016. EMarketing for Nigeria Agricultural Products. J. Innovative Res. Engi. Sci., 4.

Kumar, V., Sinha, A.K., Makkar, H.P., et al. 2010. Dietary roles of phytate and phytase in human nutrition: A review. Food Chem., 120: 945-959.

Lambri, M., Fumi, M.D., Roda, A., et al. 2013. Improved processing methods to reduce the total cyanide content of cassava roots from Burundi. African J. Biotechnol., 12.

Lancaster, P., Ingram, J., Lim, M., et al. 1982. Traditional cassava-based foods: survey of processing techniques. Economic Bot., 36: $12-45$.

Lasekan, O., Hosnas, R., Ng, S., et al. 2016. Identification of aromatic compounds and their sensory characteristics in cassava flakes and "garri"(Manihot esculenta Crantz). CyTA-J. Food, 14: 154-161.

LeBlanc, J.G., de Giori, G.S., Smid, E.J., et al. 2007. Folate production by lactic acid bacteria and other food-grade microorganisms. Communicating Curr. Res. Edu. Topics and Trends in Appl. Microbiol., 1: 329-339.

Lorri, W. and Svanberg, U. 1995. An overview of the use of fermented foods for child feeding in Tanzania. Ecol. Food and Nutri., 34: 65-81.

Mante, E.S., Sakyi-Dawson, E. and AmoaAwua, W.K. 2003. Antimicrobial interactions of microbial species involved in the fermentation of cassava dough into agbelima with particular reference to the inhibitory effect of lactic acid bacteria on 
enteric pathogens. Int. J. Food Microbiol., 89: 41-50.

Marfo, E.K., Simpson, B.K., Idowu, J.S., et al. 1990. Effect of local food processing on phytate levels in cassava, cocoyam, yam, maize, sorghum, rice, cowpea, and soybean. J. Agri. Food Chem., 38: 15801585 .

McFeeters, R. 2004. Fermentation microorganisms and flavor changes in fermented foods. J. Food Sci., 69: FMS35-FMS37.

Mestres, C., Boungou, O., Akissoe, N., et al. 2000. Comparison of the expansion ability of fermented maize flour and cassava starch during baking. J. Sci. Food and Agri., 80: 665-672.

Montagnac, J.A., Davis, C.R. and Tanumihardjo, S.A. 2009. Nutritional value of cassava for use as a staple food and recent advances for improvement. Comprehensive Reviews in Food Sci. Food Safety, 8: 181-194.

Moorthy, S. and Mathew, G. 1998. Cassava fermentation and associated changes in physicochemical and functional properties. Crit. Rev. Food Sci. Nutri., 38: 73-121.

Morales, P., Fernández-García, E., Gaya, P., et al. 2003. Formation of volatile compounds by wild Lactococcus lactis strains isolated from raw ewes' milk cheese. Int. Dairy J., 13: 201-209.

Moslehi-Jenabian, S., Lindegaard, L. and Jespersen, L. 2010. Beneficial effects of probiotic and food borne yeasts on human health. Nutrients, 2: 449-473.

Mugula, J., Nnko, S., Narvhus, J., et al. 2003. Microbiological and fermentation characteristics of togwa, a Tanzanian fermented food. Int. J. Food Microbiol., 80: 187-199.

Muoki, P.N. and Maziya-Dixon, B. 2010. Household utilization of manioc (Manihot esculenta Crantz) in northern
Mozambique. Ecology of food and nutrition, 49: 337-356.

Musuku, A. 1995. Mycotoxicologie du manioc fermenté consommé au Burundi: identification, quantification, étude neuropharmacologique des mycotoxines trémorgéniques isolées: Universitaire Instelling Antwerpen.

Muyanja, C., Narvhus, J. and Langsrud, T. 2012. Organic acids and volatile organic compounds produced during traditional and starter culture fermentation of Bushera, a Ugandan fermented cereal beverage. Food Biotechnol., 26: 1-28.

Nevry, R.K., Koussemon, M. and Aboua, F. 2007. Chemical and Organoleptic Properties of Attoukpou Made from Two Cassava (Manihot esculenta Crantz) Varieties, Bonoua and IAC. J. Food Technol., 5: 300-304.

Ngaba, P. and Lee, J. 1979. Fermentation of Casava (Manihot esculenta Crantz). J. Food Sci., 44: 1570-1571.

Nwankwo, D., Anadu, E. and Usoro, R. 1989. Cassava-fermenting organisms. MIRCEN J. Appl. Microbiol. Biotechnol., 5: 169179.

Nzigamasabo, A. 2012. Volatile compounds in Ikivunde and Inyange, two Burundian cassava products. Glob. Adv. Res. J. Food Sci. Technol., 1: 001-007.

Obilie, E.M., Tano-Debrah, K. and AmoaAwua, W.K. 2004. Souring and breakdown of cyanogenic glucosides during the processing of cassava into akyeke. Int. J. Food Microbiol., 93: 115121.

Odunfa, S. 1988. African fermented foods: from art to science. MIRCEN J. Appl. Microbiol. Biotechnol., 4: 259-273.

Odunfa, S. and Oyewole, O. 1998. African fermented foods. Microbiol. Fermented Foods, Springer, 713-752.

Oduro, I., Ellis, W., Dziedzoave, N., et al. 2000. Quality of gari from selected 
processing zones in Ghana. Food Control, 11: 297-303.

Okafor, N. 1977. Micro- organisms Associated with Cassava Fermentation for Garri Production. J. Appl. Bacteriol., 42: 279284.

Olaoye, O., Lawrence, I., Cornelius, G., et al. 2015. Evaluation of quality attributes of cassava product (gari) produced at varying length of fermentation. American J. Agri. Sci., 2: 1-7.

Oluwole, O.S.A., Onabolu, A.O., Mtunda, K., et al. 2007. Characterization of cassava (Manihot esculenta Crantz) varieties in Nigeria and Tanzania, and farmers' perception of toxicity of cassava. J. Food Composition and Analysis, 20: 559-567.

Onyango, C., Bley, T., Raddatz, H., et al. 2004. Flavour compounds in backslop fermented uji (an East African sour porridge). European Food Res. Technol., 218: 579-583.

Onzo, F., Aka, S., Azokpota, P., et al. 2015. Diversité des denrées alimentaires traditionnelles conditionnées dans les emballages des feuilles de plantes en Côte d'Ivoire. Agronomie Africaine, 27: 155-172.

Oyewole, O. and Odunfa, S. 1992. Effects of processing variables on cassava fermentation for'fufu'production. Trop. Sci.

Oyewole, O.B. 1997. Lactic fermented foods in Africa and their benefits. Food Control, 8: 289-297.

Oyewole, O.B. and Asagbra, Y. 2003. Improving traditional cassava processing for nutritional enhancement. Food-based approaches for a healthy nutrition. 2nd International Workshop. Ouagadougou. 23-28.

Oyewole Olusola, B. and Yemisi, A. 2003. Improving traditional cassava processing for nutritional enhancement. 2ème Atelier international / 2nd International Workshop Voies alimentaires d'amélioration des situations nutritionnelles Food-based approaches for a healthy nutrition, 23-28 / 11 / 2003 Ouagadougou, Burkina faso: Brouwer, Traoré,trèche, 369-382.

Padonou, S.W., Nielsen, D.S., Hounhouigan, J.D., et al. 2009. The microbiota of Lafun, an African traditional cassava food product. Int. J. Food Microbiol., 133: 22-30.

Patring, J.D., Jastrebova, J.A., Hjortmo, S.B., et al. 2005. Development of a simplified method for the determination of folates in baker's yeast by HPLC with ultraviolet and fluorescence detection. J. Agri. Food Chem., 53: 2406-2411.

Quintson, P.A.K. 2015. Effect of variety and processing methods (holding period and drying method) on quality of cassava flour (Kokonte) in the Hohoe Municipality of the Volta region of Ghana.

Raheem, D. and Chukwuma, C. 2001. Foods from cassava and their relevance to Nigeria and other African countries. Agriculture and Human Values, 18: 383390.

Ray, R.C. and Sivakumar, P.S. 2009. Traditional and novel fermented foods and beverages from tropical root and tuber crops: review. Int. J. Food Sci. Technol., 44: 1073-1087.

Rosales-Soto, M., Ross, C. and Younce, F. 2016. Physico-chemical and sen-sory evaluation of cooked fermented protein fortified cassava (Manihot es-culenta Crantz) flour. Adv. Food Technol. Nutri. Sci., 2: 9-18.

Ross, R.P., Morgan, S. and Hill, C. 2002. Preservation and fermentation: past, present and future. Int. J. Food Microbiol., 79: 3-16.

Rwamudanga, E. 1988. Effets des traitements technologiques sur quelques propriétés chimiques du manioc. Mémoire: 
Université du Burundi, Bujumbura (Burundi).

Schwan, R.F., do Amaral Santos, C.C.A., Santos, M.R.R.M., et al. 2014. Bacterial dynamics and chemical changes during the spontaneous production of the fermented porridge (Calugi) from cassava and corn. African J. Microbiol. Res., 8: 839-849.

Silvestre, P. 1989. Cassava: Macmillan.

Soro-Yao, A.A., Brou, K., Koffi-Nevry, R., et al. 2013. Microbiology of Ivorian fermented products: A review. Asian $J$. Agri. Food Sci., (ISSN: 2321-1571) 1.

Uyoh, E., Ntui, V. and Udoma, N. 2009. Effect of local cassava fermentation methods on some physiochemical and sensory properties of fufu. Pak. J. Nutri., 8: 11231125.

Uzogara, S., Agu, L. and Uzogara, E. 1990. A review of traditional fermented foods, condiments and beverages in Nigeria: Their benefits and possible problems. Ecol. Food Nutri., 24: 267-288.

Wakil, S. and Benjamin, I. 2015. Starter developed pupuru, a traditional Africa fermented food from cassava (Manihot esculenta). Int. Food Res. J., 22: 25652570.

Yao, A., Koffi, D.M., Blei, S.H., et al. 2015. Propriétés biochimiques et organoleptiques de trois mets traditionnels ivoiriens (attiéké, placali, attoukpou) à base de granulés de manioc natifs. Int. J. Biol. Chem. Sci., 9: 13411353.

Zannou-Tchoko, V.J., Ahui-Bitty, L.B., Kouame, K., et al. 2011. Utilisation de la farine de maïs germé source d'alphaamylases pour augmenter la densité énergétique de bouillies de sevrage à base de manioc et de son dérivé, l'attiéké. $J$. Appl. Biosci., 37: 2477-2484.

Zhu, C., Cai, Y., Gertz, E.R., et al. 2015. Red palm oil-supplemented and biofortified cassava gari increase the carotenoid and retinyl palmitate concentrations of triacylglycerol-rich plasma in women. Nutri. Res., 35: 965-974.

\section{How to cite this article:}

Guira Flibert, Tankoano Abel and Savadogo Aly. 2016. African cassava Traditional Fermented Food: The Microorganism's Contribution to their Nutritional and Safety Values-A Review. Int.J.Curr.Microbiol.App.Sci. 5(10): 664-687. doi: http://dx.doi.org/10.20546/ijcmas.2016.510.074 